Ю. П. Спіженко 1 , С. М. Лучковський ${ }^{1,2}$, І. М. Каденко ${ }^{2}$

${ }^{1}$ Кібер клініка Спіженка, Капітанівка

${ }^{2}$ Київський національний університет

імені Тараса Шевченка

\section{Оцінка величини}

\section{поглиненої дози}

\section{в розрахунках плану \\ опромінення злоякісних} пухлин легенів у пацієнтів із застосуванням системи CyberKnife

Наведено результати розрахунків із заниженням на $29 \%$ величини дози при використанні алгоритму Ray-Tracing, а також розглянуто зміщення в розподілі дози до здорової тканини пацієнта в планах із розташуванням пухлини на краю легеневої тканини з низькою масовою густиною. Запропоновано та проаналізовано проведення обов'язкового перерахунку дози алгоритмом Монте-Карло в процесі планування опромінення пацієнтів із пухлинами легенів для усунення значних систематичних похибок величини доведеної дози.

Ключові слова: CyberKnife; SBRT; доведена доза, розрахунок дози.

\section{Ю. П. Спиженко, С. Н. Лучковский, И. Н. Каденко}

Оценка величины поглощенной дозы при расчетах плана облучения злокачественных опухолей лёгких у пациентов с применением системы CyberKnife

Приведены результаты расчетов с занижением на $29 \%$ величины дозы при использовании алгоритма Ray-Tracing, а также рассмотрен сдвиг в распределении дозы в сторону здоровой ткани в планах с расположением опухоли на краю легочной ткани с низкой массовой плотностью. Предложено и проанализировано проведение обязательного перерасчета дозы алгоритмом Монте-Карло при планировании облучения пациентов с опухолями лёгких для устранения значительных систематических погрешностей величины подводимой дозы.

Ключевые слов а: CyberKnife; SBRT; алгоритмы расчёта дозы.

(C) Ю.П.Спіженко, С. М. Лучковський, І.М.Каденко, 2011

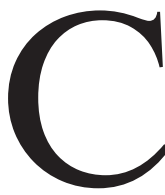

вітова тенденція заміни ізотопних (як правило, кобальтових) дистанційних радіотерапевтичних установок на медичні лінійні прискорювачі є сталою протягом тривалого часу. Як наслідок, багато медичних фізиків у світі взагалі ніколи не працювали на кобальтових установках. Проте в Україні кількість лінійних прискорювачів для використання в медицині зростає невеликими темпами, основним обладнанням все ще залишаються ізотопні установки. Хоча лінійні прискорювачі дорожчі, ніж кобальтові установки, вони мають низку важливих переваг. По-перше, лінійні прискорювачі не потребують заміни ізотопних джерел. По-друге, в лінійних прискорювачах енергія фотонів вища за енергію гамма-квантів з кобальтового джерела, а отже, зменшується ушкодження шкіри. Крім того, в них реалізовано опцію використання декількох енергій гальмівних фотонів для вирішення специфічних завдань у разі опромінення уражених органів, а також застосування пучка електронів. Дана перевага особливо проявляється в універсалізації лінійних прискорювачів щодо можливості лікування пухлин 3 різною глибиною залягання та для зменшення ушкодження навколишніх тканин.

Подальший розвиток технології застосування лінійних прискорювачів для лікування онкохворих отримали 3 переходом до складних систем доведення дози до пухлини. Використання лінійних прискорювачів з рентгенівськими джерелами, оптичними пристроями та іншим обладнанням дає змогу застосовувати нові методики в радіаційній онкології, а саме: IMRT (радіотерапія з модуляцією інтенсивності), IGRT (радіотерапія з керуванням зображення), SRT та SBRT (стереотаксична радіотерапія), SRS (стереотаксична радохірургія) тощо. Їсторія виникнення та розвитку радіохірургії пов'язана з кобальтовою установкою гамма-ніж (GammaKnife) [1], проте сьогодні у радіохірургії пухлин різної локалізації, через обмеженість можливостей гамма-ножа, використовуються такі сучасні системи, як CyberKnife, Novalis та LINAC (від різних виробників). Застосування даних систем потребує засобів для прецизійного доведення високої разової дози до пухлини (мішені) з мінімальними похибками, а основними джерелами похибок є: укладка пацієнта (зумовлює як первинну - систематичну, так і щоденну - статистичну [2] похибки), робота системи відстеження мішені та рух органів пацієнта між пучками; похибка абсолютної дози, похибка в процесі планування тощо. Варто звернути увагу на похибку в процесі планування. На даному етапі можна виділити дві основні складові такої похибки: оконтурення мішені й критичних органів та похибка розрахунку дози. Предметом цієї роботи є похибка розрахунку дози з використанням системи MultiPlan для лікування пухлин легенів.

У звіті Американської асоціації фізиків у медицині (AAPM) Task Group № 65 (report № 85, 2004) [3] зазначається, що похибка доведеної дози має бути в межах 4,4-6,6 \% при похибці в розрахунку дози 1-5\% відповідно. В майбутньому похибку доведеної дози слід скоротити до 2,7-3,9 \% при похибці розрахунку дози 1-3\%. За рекомендаціями МАГАTE TRS398 [4] остання похибка не може перевищувати $5 \%$. В той же час у багатьох системах планування похибка розрахунку дози аналітичними методами (зв икористанням методу pencil beam [5] тощо) взагалі не вказується. В розрахунках дози алгоритмами методу Монте-Карло (МК) статистична похибка є завжди і навіть може задаватися для конкретного випадку залежно від розіграшу історій фотонів та сітки розрахунку дози. Проте 


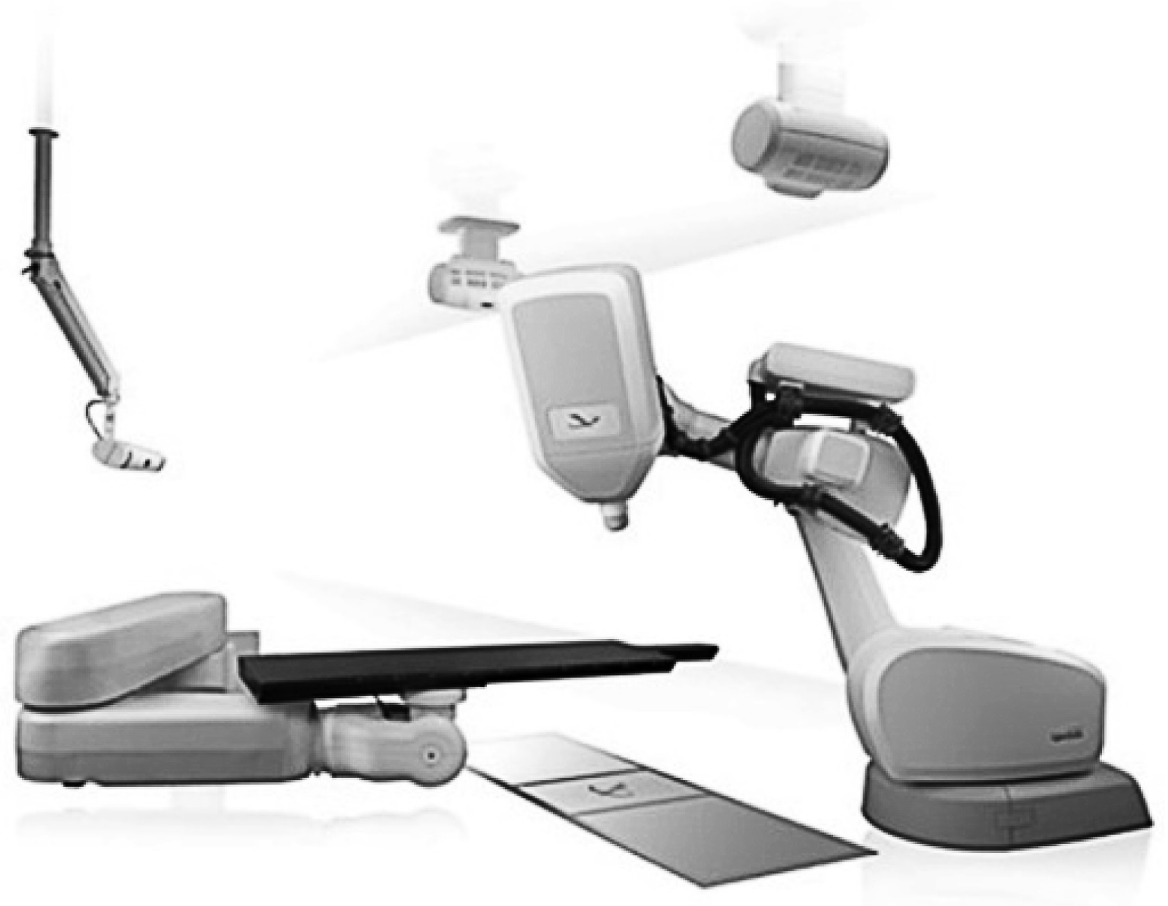

Рис. 1 . Радіохірургічна стереотаксична система CyberKnife G4

залишається відкритим питання про те, з якою похибкою розраховано дозу іншими алгоритмами, відмінними від тих, що базуються на методі МК.

У літературі широко представлено результати успішного лікування недрібноклітинного раку легенів (NSCLC) T1-2N0M0 та метастазів у легенях із застосуванням системи CyberKnife [6]-[15], але, в більшості випадків, не наведено опису методів розрахунку поглиненої дози - лише на підставі формату наведених рисунків можна припустити, що розрахунок робився з використанням алгоритму Ray-Tracing (RT). За результатами проведених досліджень [16]-[20] у разі застосування алгоритму RT при опромінюванні гетерогенної тканини з'являється суттєва різниця в розподілах поглинених доз між виміряними значеннями та розрахованими за алгоритмом RT величинами. Дана різниця пов'язана з тим, що алгоритм RT використовує простий метод корекції гетерогенності - метод еквівалентної довжини шляху, який фактично звужує напівтінь пучка в області з малою густиною тканини, зменшуючи поглинання первинних фотонів, але в той же час не враховуючи збільшення вторинних електронів [20]. Subhash C. Sharma та інші показали [19], що найкращу збіжність з експериментальними значеннями забезпечує використання алгоритму МК, оскільки при цьому враховується розподіл вторинних електронів. Різниця в розподілах доз між алгоритмами МК та RT може сягати 15-28 \% [19], тому після перерахунку плану опромінення легенів пацієнта, розрахованим за RT та перерахованим за МK, в абсолютній більшості випадків доза для пацієнта є нижчою від такої, що має бути доведеною до пухлини. Ця різниця може бути більшою або меншою залежно від розмірів та розташування мішені, але, як правило, вона значно перевищує максимально прийнятне значення похибки розрахунку дози в $5 \%$.

Сьогодні Accuray - компанія-виробник систем CyberKnife - рекомендує перераховувати плани опромінювання пацієнтів 3 використанням MK у випадку гетерогенності тканин, що опромінюються (легені). Проте основним алгоритмом розрахунку залишається RT. Програмне забезпечення з реалізованим алгоритмом MK не входить до стандартної комплектації системи CyberKnife і може бути поставленим за окрему плату. Якщо ж такий підхід не можна реалізувати, рекомендується робити розрахунок алгоритмом RT, але доведену дозу збільшувати на 10-15\%. Ми досліджували різницю в розподілах поглиненої дози, розрахованих з використанням обох алгоритмів, та порівнювали результати розрахунків з виміряним розподілом поглиненої дози, отриманим з використанням радіохромної плівки на легеневому фантомі, а також оціненим для пролікованих пацієнтів. МК алгоритм застосовано у реалізації, що є доступною від Accuray.

Методи та експериментальні вимірювання. Система CyberKnife (рис. 1) - одна 3 найсучасніших розробок у галузі радіаційної онкології, яка дає змогу лікувати не тільки внутрішньочерепні, сферичні пухлини, а й пухлини складної форми головного мозку та іншої локалізації. На даний момент у світі встановлено більше 200 таких систем і проліковано понад 90 тисяч пацієнтів [21]. CyberKnife було розроблено Джоном Адлером у 1994 p. в Стенфордському університеті. Роботизована стереотаксична радіохірургічна система CyberKnife являє собою робот-маніпулятор з шістьма степенями вільності (KUKA Roboter GmbH, Germany), на якому встановлено компактний $6 \mathrm{MeB}$ лінійний прискорювач (linac). Для колімації пучків використовуються 12 коліматорів з круглими отворами діаметром 5-60 мм на відстані SAD=800 мм (SAD відстань від джерела випромінювання до центру мішені) [22]. Якщо орган, який опромінюється, рухається в такт диханню, для імітації дихальних рухів з метою максимально прецизійного доведення розрахованої дози до визначеної частини тіла пацієнта використовується система синхронізації (Synchrony). Дана системи дозволяє, по-перше, зменшити відступ до мішені (ITV - internal target volume, 
використовується у випадку руху мішені з диханням) або взагалі не використовувати даний відступ; по-друге, не зупиняти пучок після виходу мішені з певної фази дихання. Робот-маніпулятор під час опромінення рухається в такт з дихальними рухами за заздалегідь побудованою моделлю, що в подальшому коригується. Побудова та наступні корекції моделі руху мішені здійснюються з використанням двох рентгенівських джерел, розташованих під кутом $45^{\circ}$ до мішені та під кутом $90^{\circ}$ один до одного. Для отримання гарного покриття мішені період дихальних коливань розбивається на 8 фаз - точок синусоїдальної кривої. В кожній з цих точок робиться рентгенівське зображення для відстеження зміщення мішені внаслідок дихальних рухів. Отримують дані точки перед початком лікування, в подальшому перед кожним новим пучком роблять нові рентгенівські знімки. Таким чином, модель самокоригується.

Системою планування для CyberKnife $€$ MultiPlan, а основним алгоритмом розрахунку дози - алгоритм RT. Даний алгоритм при обчисленні дози в певному вокселі (елементі об’єму) використовує три набори таблиць, отримані з вимірювань на водному фантомі: 1) відношення тканина-фантом $(T P R)$ - значення $T P R$ для кожного коліматора нормуються на одиницю на глибині 15 мм; 2) коефіцієнт корекції розсіяння $(O C R)-$ значення $O C R$ для кожного коліматора приводиться до одиниці для радіусу 0 мм; 3) коефіцієнт виходу $(O F)$ - значення $O F$ для кожного коліматора приводиться до величини $O F$, визначеної як 1,0 мм для коліматора 60 мм при $S A D=800$ мм. Віднормована доза $D$ у кожній точці, що вноситься пучком, розраховується за формулою

$$
\begin{aligned}
& \frac{D}{M U}=\operatorname{OCR}\left(\text { coll, } R_{800}, D_{\text {eff }}\right) \cdot\left(\frac{800}{S A D}\right)^{2} \times \\
& \times T P R\left(\text { fieldsize, } D_{\text {eff }}\right) \cdot \operatorname{DM}(\text { coll }, S A D),
\end{aligned}
$$

де coll - коліматор; $R_{800}-$ ексцентричний радіус, спроектований до 800 мм; $D_{\text {eff }}$ - ефективна глибина; fieldsize розмір поля $\left(F S=\right.$ Coll $\left._{\text {Diameter }} \cdot\left(\frac{S A D}{800}\right)\right) ; M U-$ моніторні одиниці [23].

І̇ншим доступним алгоритмом розрахунку дози в системі планування MultiPlan є алгоритм, побудований на основі методу МК. Даний алгоритм був розроблений спільно компаніями Accuray та Fox Chase Cancer Center. Biн охоплює багато ідей з раніш розроблених даною групою алгоритмів, наприклад MCDOSE, DOSIMETER, MCSIM та МСBEAM [23].

Для отримання експериментальних данних, що мають співвідноситися з показниками дозиметрів, нами використовувалася радіохромна плівка MD-55, розрахована на вимірювання дози в діапазоні 2-100 Гр [24]. Усі плівки сканувалися на сканері Epson Expression 100000XL. Для калібровки плівки використано одну неопромінену (фонову) плівку та 14 опромінених від $1000 \mathrm{MU} \quad(100 M U=100 \mathrm{c \Gamma р}, \quad$ при $S A D=800 \mathrm{мm} \quad$ та $D_{\text {eff }}=15$ мм) до $7500 M U$ з кроком $500 M U$. Опрацювання плівок здійснювалось у програмі ImageJ. Їнтенсивність плівок визначалась як середнє значення інтенсивності в центральній області плівки. Потім інтенсивність було перераховано в оптичну густину $(O D)$ для визначення залежності дози від неї: $D=f(O D)$. За похибку оптичної

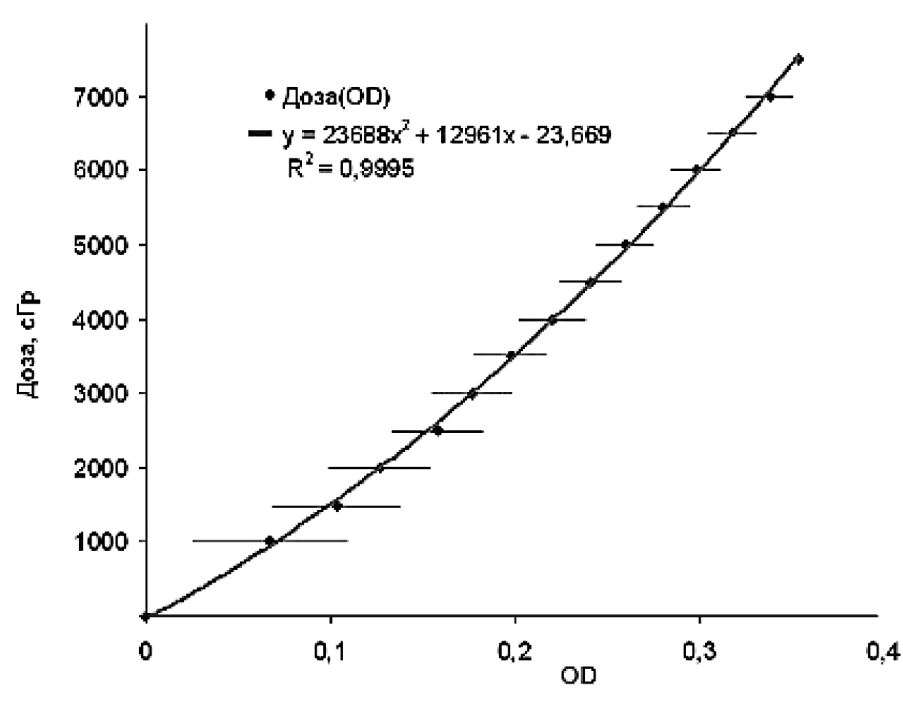

Рис.2 . Калібрувальна крива залежності дози від оптичної густини

густини бралося стандартне відхилення від середнього, визначене $з$ формули непрямих вимірів:

$$
\begin{aligned}
\Delta O D & =\sqrt{\left(\Delta(\text { Intensity }) \cdot \frac{d(O D)}{d(\text { Intensity })}\right)^{2}}= \\
& =\sqrt{\left(0,01 \cdot \frac{1}{\text { Intensity } \cdot \ln (10)}\right)^{2}},
\end{aligned}
$$

де $O D=\log _{10}\left(\frac{a}{\text { Intensity }}\right)$ - оптична густина, за визначенням; $a=51007$ - фонова інтенсивність; Intensity - ceредня інтенсивність опроміненої плівки, що виміряна з використанням програми ImageJ; $\triangle O D-$ стандартне відхилення середнього значення оптичної густини.

Для апроксимації отриманої залежності доза-оптична густина використано поліном 2-го порядку (згідно з рекомендаціями Accuray [23]) (рис.2 ).

Для перевірки коректності величини дози створено план з використанням системи планування MultiPlan (Accuray Inc.) для фантому CIRS Dynamic Thorax Phantom 008 (рис. 3, a) з імітацією дихання. Спочатку за допомогою алгоритму розрахунку дози RT був згенерований ізоцентричний план з різноваговими пучками з використанням алгоритму розрахунку дози RT. Потім план перераховано алгоритмом МК з похибкою $1 \%$. У фантом, в спеціальний куб (рис. 3, б), вставлялися взаємно перпендикулярні радіохромні плівки MD-55. Обидва плани було збережено для подальшого опромінення плівки. Приписана доза 2100 сГр до 70 \% від максимальної дози була доставлена 87 ізоцентричними пучками. Під час опромінення фантому використовувалась система врахування дихання (в даному випадку імітації дихання) Synchrony Respiratory Tracking System.

Результати. Після опромінення фантому двома планами, чотири плівки: по дві для кожного плану аксіальної (anterior-left - AL) та сагітальної (anterior-superior - AS) проекцій, розташовані взаємно перпендикулярно у фантомі, були проаналізовані. На підставі попередньо проведеної калібровки інтенсивність плівки переведено у величину 


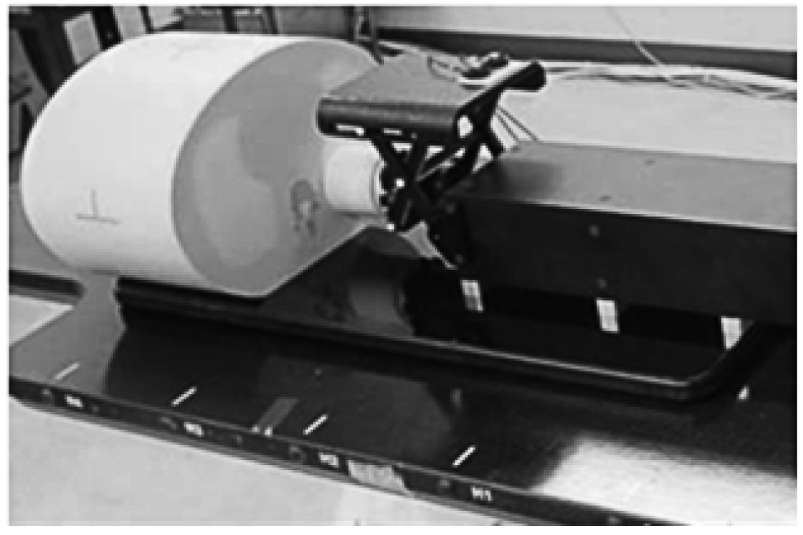

$a$

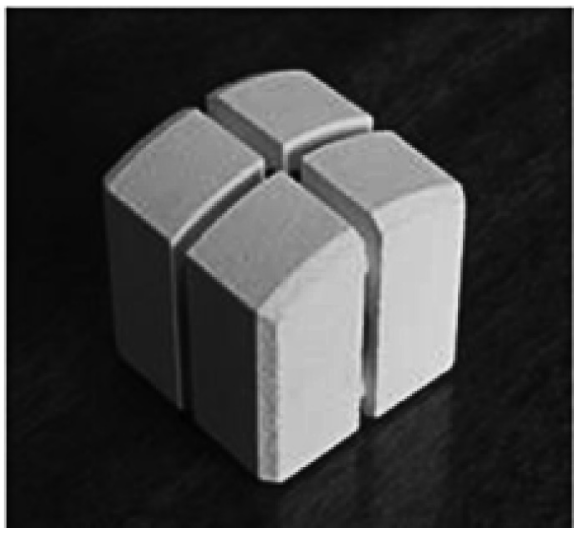

б

Рис. 3. Фантом CIRS Dynamic Thorax Phantom 008: $a-$ загальний вигляд; $\sigma-$ куб для розміщення радіохромної плівки у фантом

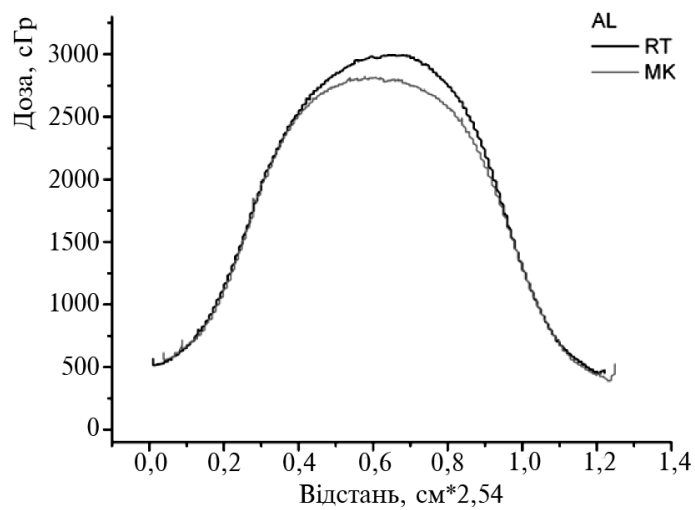

$a$

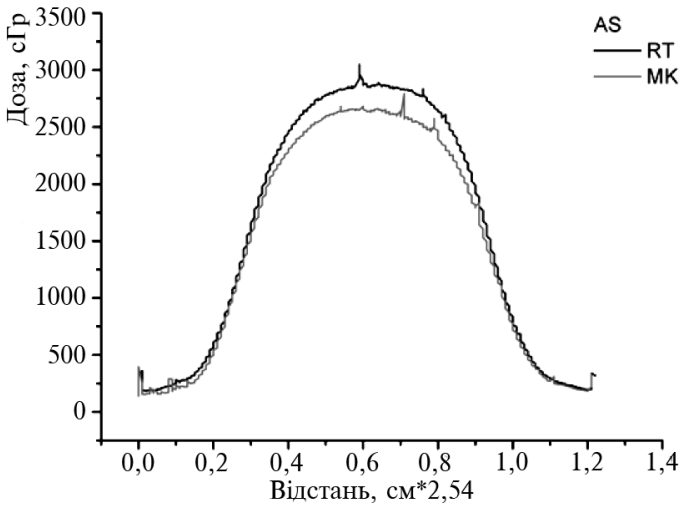

б

Рис. 4. Порівняння профілю дози для RT та MK: $a$ - для плівки AL; $\sigma-$ для плівки AS

доведеної дози. Для уникнення «артефактних» піків на профілях дози проведено процедуру згладжування, проте на плівках AS все ж залишилось кілька нерівномірностей. Порівняння профілів доз планів RT та MK(рис. 4) показало, що алгоритм RT завищив дозу на 7 \% порівняно з алгоритмом МК. При цьому приписана доза зменшилась на 2 Гр, що може відігравати значну роль у лікуванні пацієнта.

У клінічній практиці Кібер клініки Спіженка при розрахунку дози на пухлини легенів перерахунок дози з використанням алгоритму МК є обов'язковим, 3 можливою подальшою оптимізацією плану (за необхідності). Прикладом завищення дози алгоритмом RT є план, розрахований для пацієнта, пролікованого в Кібер клініці Спіженка $з$ периферійним раком легенів. На рис. 5 показано аксіальний зріз плану з контурами органів та пухлини і розподілом дози, а також гістограми доза - об'єм (DVH). У плані RT приписана доза дорівнювала 60 Гр за три фракції, ізодоза - 84 \% максимальної. Покриття CTV (мішень, оконтурена рентгенологом) склало $100 \%$, а PTV (мішень, на яку приписується доза і що включає похибку укладки та похибку доведення дози) - більше 95 \%. Проте, коли план був перерахований алгоритмом МК (без оптимізації, з тим самим набором пучків та вагових коефіцієнтів), покриття як CTV, так і PTV значно зменшилось внаслідок попереднього завищення дози. Для гарного покриття мішені довелося зменшити поріг припису ізодозної лінії до $65 \%$, залишивши приписану дозу 60 Гр. Внаслідок цього максимальна доза збільшилась з 7143 сГр до 9230 сГр. Таким чином, різниця в розрахунку дози за двома алгоритмами склала $29 \%$, а приписану ізодозну лінію довелось зменшити на $19 \%$.

Подальший результат порівняння двох алгоритмів показує другу важливу причину для необхідності перерахунку дози методом МК у разі розрахунку дози в легенях. На рис. 5 і 6 зображено аксіальні зрізи планів пацієнта з метастазом в легені. Для даного пацієнта був розроблений план опромінення з приписаною дозою 45 Гр за три фракції на PTV $=\mathrm{GTV}+5$ мм. Доза доставлена 45 ізоцентричними різноваговими пучками з розміром коліматора 25 мм. Початковим був план, розрахований алгоритмом RT з центруванням коліматора на PTV (рис. 6, a). Приписана ізодозна лінія в $82 \%$ покривала більше $95 \%$ PTV. Наступний крок був пов'язаний з перерахунком розподілу дози методом МК без зміни параметрів. Внаслідок нами отримано ізодозний розподіл, що представлений на рис. 6, б. 3 отриманих результатів випливає, що приписана ізодоза складала $82 \%$ та є зміщеною в напрямку входження променів, а покриття PTV склало лише 49 \%. І̇з зменшенням приписаної ізодози до $70 \%$ (рис. 7, a) покриття PTV зросло, але при цьому 


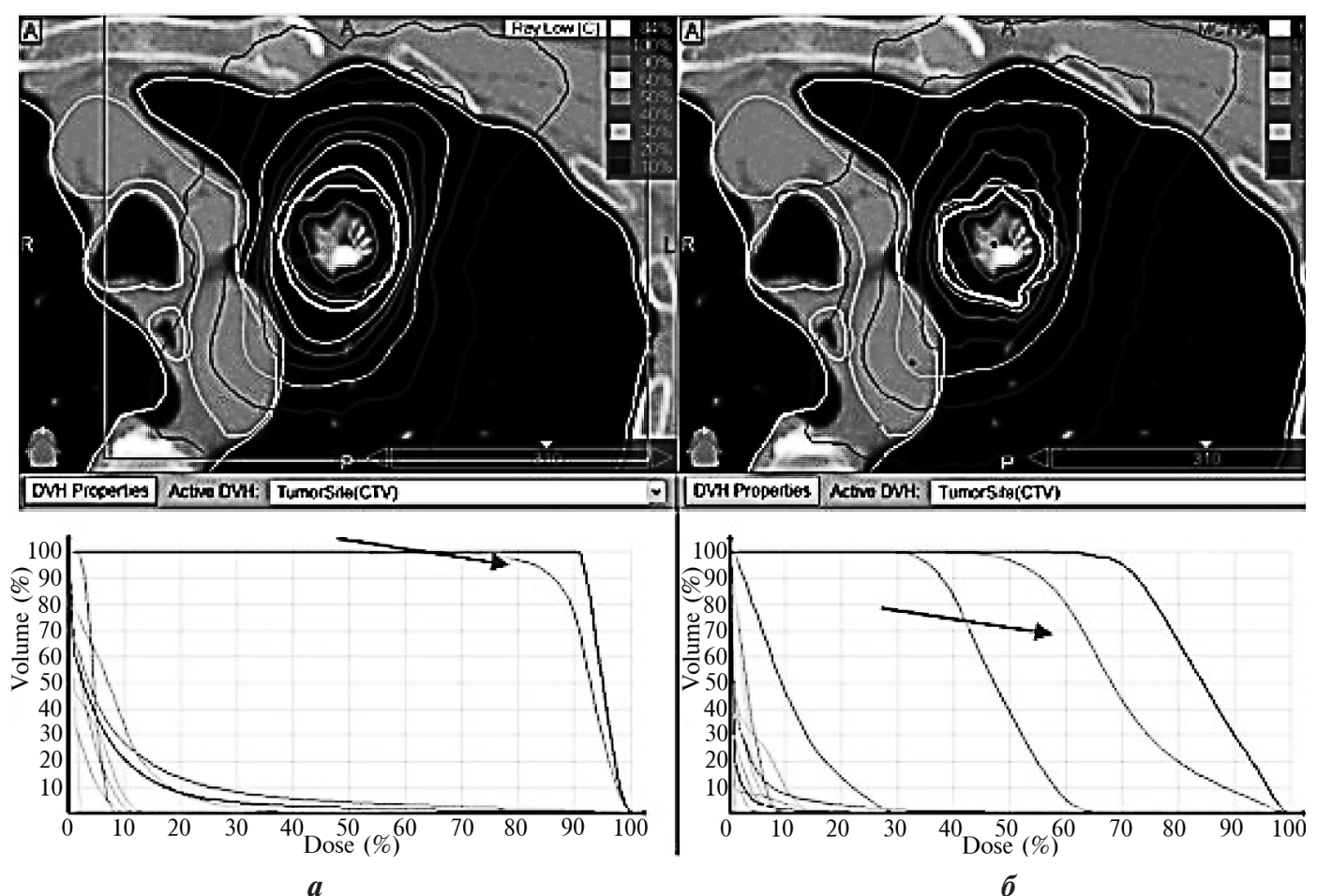

Рис. 5. Аксіальний зріз та DVH плани:

$a-\mathrm{RT}$ з приписаною дозою $84 \%-60$ Гр; б - МК з приписаною дозою $65 \%-60$ Гр
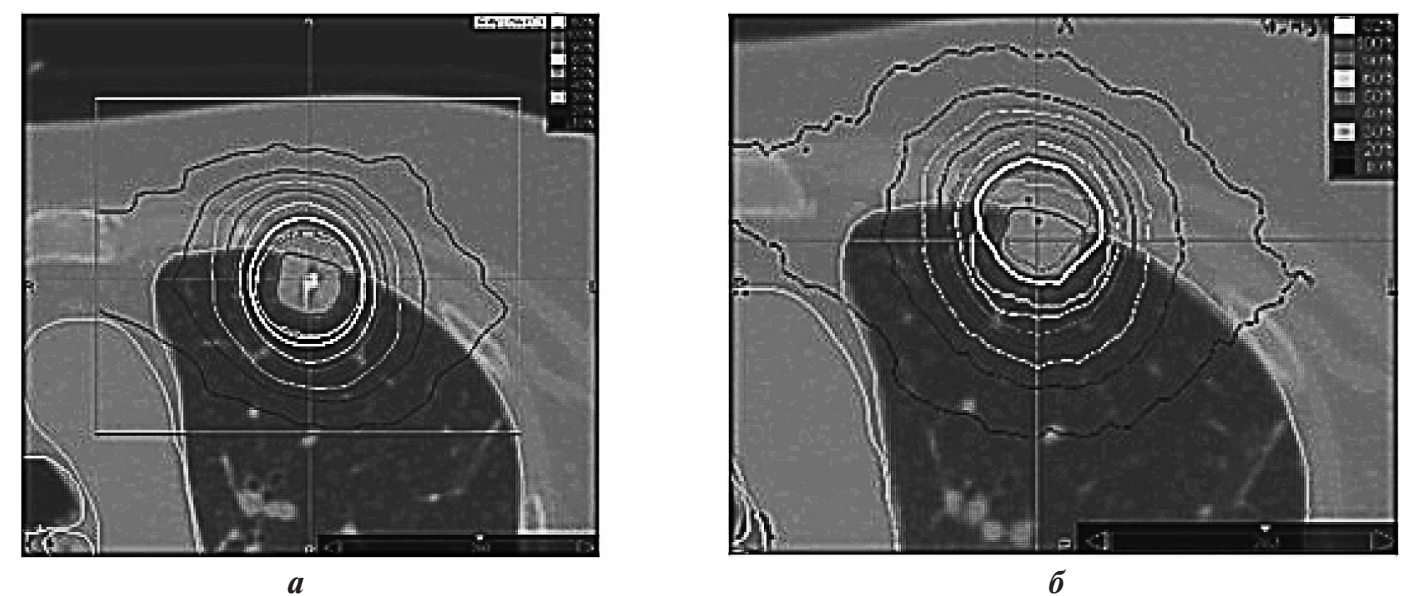

б

Рис. 6. Аксіальний зріз планів з приписаною дозою $82 \%-4500$ сГр: $a-\mathrm{RT} ; \sigma-\mathrm{MK}$

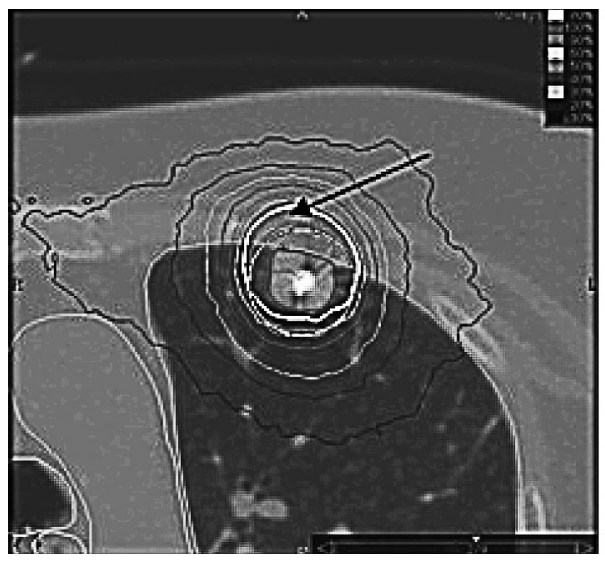

a

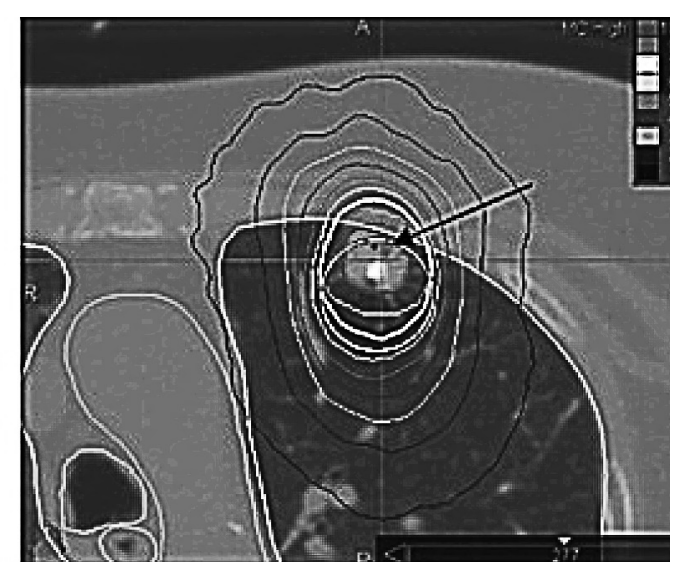

б

Рис. 7. Аксіальний зріз планів з приписаною дозою $70 \%-4500$ сГр: $a-\mathrm{MK}$ до зміщення ізоцентра; $\sigma$ - МК після зміщення ізоцентра 
збільшився об’єм плевральної тканини та ребер, які отримують дозу, більшу за 45 Гр, що може спричинити значні ускладнення для пацієнта.

Отже, без перерахунку дози планів RT методом МK однозначно має місце заниження дози в мішені, але при цьому в деяких випадках може спостерігатися перевищення дози внаслідок переопромінення критичних (нормальних) тканин, що може призвести до важких наслідків. У даному випадку для вирівнювання розподілу дози нам вдалося змістити центрування пучків у глибину для зменшення дози на передню частину грудної клітини та кращого покриття задньої частини PTV (рис. 7, б).

\section{Висновки}

Нами підтверджено значне відхилення, що має місце у розрахунках дози для опромінення уражених легенів пацієнта двома алгоритмами (RT та MK) у разі значної гетерогенності тканини при використанні системи планування MultiPlan компанії Accuray. Дана різниця може сягати 29 \% і проявлятися не лише внаслідок завищення величини доведеної дози в алгоритмі розрахунку RT, але й бути зумовленою значними змінами у розподілу дози, що може призводити до перевищення толерантної дози на критичні органи.

Тому використання розрахунків плану опромінення лише за алгоритмом RT неприйнятні, обов'язковим $€$ перерахунок дози методом МK у разі значної гетерогенності тканин з урахуванням наведених нами систематичних похибок.

\section{Список літератури}

1. Chin L. S., Regine W. Principles and Practice of Stereotactic Radiosurgery. - N.-Y., 2008. - P.107127-.

2. De Boer J. C. J., van Sornsen de Koste J. R., Senan S., Viss$\operatorname{er} A$. G., Heijmen B. J. M. Analysis and reduction of 3D systematic and random setup errors during the simulation and treatment of lung cancer patients with CT-based external beam radiotherapy dose planning // Int J Radiation Oncology Biol. Phys. - 2001. - V. 49. - P. 857-868.

3. Papanikolaou N. et al. Tissue inhomogeneity corrections for megavoltage photon beam: Recommendations of AAPM Radiation Therapy Committee Task group 65. - Madison, WI (USA): Medical Physics Publishing, 2004. - P. 3-9.

4. International Atomic Energy Agency, Absorbed Dose Determination in External Beam Radiotherapy: An International Code of Practice, Technical Reports Series No. 398. - 2000. - P. 1.

5. Ahnesju A., Saxner M. and Trepp A. A pencil beam model for photon dose calculation // Med. Phys. - 1992. - V. 19, № 2. P. 263-273.

6. Collins B. T., Erickson K., Reichner C. A., et al. Radical stereotactic radiosurgery with real-time tumor motion tracking in the treatment of small peripheral lung tumors // Radiation Oncology. 2007. - V. 239, № 2. - P. 1-7.

7. Hara W., Soltys S. G. and Gibbs I. C. CyberKnife ${ }^{\circledR}$ Robotic Radiosurgery system for tumor treatment // Expert Rev. Anticancer Ther. - 2007. - V. 7, №. 11. - P. 1507-1515.

8. Brown W. T., Wu X., Fowler J. F. et al. Lung metastases treated by CyberKnife ${ }^{\circledR}$ Image-Guided Robotic Stereotactic Radiosurgery at 41 Months // Southern Medical Journal. - 2008. - V. 101, № 4. P. $376-382$.
9. Coon D., Gokhale A. S., Burton S. A., et al. Fractionated stereotactic body radiation therapy in the treatment of primary, recurrent, and metastatic lung tumors: the role of positron emission tomography/computed tomography-based treatment planning // Clinical Lung Cancer. - 2008. - V. 9, № 4. - P. 217-221.

10. Hof H., Herfarth K. K., Mbnter M., et al. Stereotactic single-dose radiotherapy of stage I non-small-cell lung cancer (NSCLC) // Int. J. Radiation Oncology Biol. Phys. - 2003. - V. 56, № 2. - P. 335341.

11. McGarry R. C., Papiez L., Williams M., et al. Stereotactic body radiation therapy of early-stage non-small-cell lung carcinoma: phase I study // Int. J. Radiation Oncology Biol. Phys. -2005. - V. 63, № 4. - P. 1010-1015.

12. Hoyer M., Roed H., Hansen A. T., et al. Prospective study on stereotactic radiotherapy of limited-stage non-small-cell lung cancer // Int. J. Radiation Oncology Biol. Phys. - 2006. - V. 66, № 4. - Supplement. - P. S128-S135.

13. Van der Voort N. C., van Zyp P. J.-B., Hoogeman M. S., et al. Stereotactic radiotherapy with real-time tumor tracking for non-small cell lung cancer: Clinical outcome // Radiotherapy and Oncology. 2009. - V. 91. - P. 296-300.

14. Wulf J., Haedinger U., Oppitz U., et al. Stereotactic radiotherapy for primary lung cancer and pulmonary metastases: a noninvasive treatment approach in medically inoperable patients // Int. J. Radiation Oncology Biol. Phys. - 2004. - V. 60, № 1. - P. 186-196.

15. Non-invasive stereotactic. radiosurgical treatment of. nonsmall cell lung cancer. Case study. The CyberKnife Centre London. http://www.cyberknifecentrelondon.co.uk/download_file.php?id=9.

16. Wilcox E. E., Daskalov G. M. Accuracy of dose measurements and calculations within and beyond heterogeneous tissues for $6 \mathrm{MV}$ photon fields smaller than $4 \mathrm{~cm}$ produced by Cyberknife // Med. Phys. - 2008. - V. 35. - P. 2259-2266.

17. Wilcox E. E., Daskalov G. M., Lincoln H., et al. Comparison of planned dose distributions calculated by monte carlo and raytrace algorithms for the treatment of lung tumors with cyberknife: a preliminary study in 33 patients // Int. J. Radiation Oncology Biol. Phys. - 2010. - V. 77, №. 1. - P. 277-284.

18. Vanderstraeten B., Reynaert N., Paelinck L., et al. Accuracy of patient dose calculation for lung IMRT: A comparison of Monte Carlo, convolution/superposition, and pencil beam computations // Med Phys. - 2006. - V. 33. - P. 3149-3158.

19. Subhash C. Sharma, Joseph T. Ott, Jamone B. Williams, et al. Clinical implication of adopting Monte Carlo treatment planning for CyberKnife // Journal of Applied Clinical Medical Physics. - 2010. V. 11, № 1. - P. 170-175.

20. Van der Voort N. C., Hoogeman M. S., van de Water S., et al. Clinical introduction of Monte Carlo treatment planning: A different prescription dose for non-small cell lung cancer according to tumor location and size // Radiotherapy and Oncology. - (article in press).

21. http://accuray.com/CorporateInfo/History.aspx

Antypas C. and Pantelis E. Performance evaluation of a CyberKnife ${ }^{\circledR}$ G4 image-guided robotic stereotactic radiosurgery system // Phys. Med. Biol. - 2008. - V. 53. - P. 4697-4718.

22. Accuray Physics Essentials Guide 2009. Cyberknife System Manual. - Sunnyvale, CA: Accuray(tm) Inc.

23. Niroomand-Rad et al. Radiochromic film dosimetry: Recommendations of AAPM Radiotion Therapy Committee Task group 55 // Med.Phys. - 1998. - V. 25, № 11. - P. 2093-2115. 